\title{
WIND TUNNEL TEST AND NUMERICAL SIMULATION FOR PRESSURE AND VELOCITY FIELD AROUND CROSS-VENTILATED BUILDING 通風時の建物周辺の圧力場及び風速場に関する風洞実験と数值解析
}

\author{
Tomohiro KOBAYASHI ${ }^{* 1}$, Hisashi KOTANI ${ }^{* 2}$, Toshio YAMANAKA*3, \\ Kazunobu SAGARA ${ }^{* 4}$, Yoshihisa MOMOI ${ }^{* 5}$ and Kaori ASAI ${ }^{* 6}$ \\ 小林知広, 甲谷寿史, 山中俊夫，相良和伸 \\ 桃井良尚, 浅井香里
}

\begin{abstract}
The objective of this work is to analyse dissipation and transportation of energy inside stream tubes passing through/around a crossventilated building, which is not sufficiently known and is required for an establishment of an improved prediction method of flow rate for wind induced cross-ventilation. This paper focuses on velocity and pressure distribution around a building because it is to be analysed to evaluate the energy loss due to divergence and confluence of the stream tubes. Although this can be done by using CFD, they must also be clarified by measurement in advance to verify the accuracy of CFD afterwards. First, velocity distribution is shown by using Particle Image Velocimetry (PIV). To measure spatial static pressure, a five-hole pitot tube is used. This device can provide three flow quantities simultaneously, i.e., static pressure, velocity magnitude, and wind direction. By comparing results between measurement and CFD conducted in the previous work, this paper finally presents both accuracy of CFD around building model and the scope of each experimental technique
\end{abstract}

Keywords : Cross-Ventilation, Wind Tunnel Test, CFD, PIV, Five-Hole Pitot Tube, Fluid Measurement Technique 通風，風洞実験，CFD，PIV，5 孔ピト一管，流体測定法

\section{Introduction}

In predicting flow rate of a building naturally ventilated by wind, the Orifice equation shown below is usually applied.

$$
Q=C_{D} A_{\text {Opening }} V \sqrt{C p_{W}-C p_{L}}
$$

where, $C_{D} A_{\text {Opening }}$ is a connected value of effective opening area and $C p_{W}$ and $C p_{L}$ are wind pressure coefficient for windward and leeward opening respectively, which are obtained from a sealed building model. For crossventilation, it is well known that the predicted flow rate could be smaller than actual one. The authors ${ }^{1)}$ showed that it could be predicted to be approximately $60 \%$ if the openings are extremely large. Ishihara ${ }^{2)}$ postulated that the effective opening area cannot be simply summed up for crossventilated room but be modified by introducing correction factor named Interference Coefficient. Many other researchers ${ }^{3-5}$ ) have worked for this problem, but there exists no improved prediction method which can be used practically. The authors focuses on the prediction method based on energy balance inside stream tube passing through/around a building, i.e., Power Balance Model, which was proposed by Murakami et al. ${ }^{6)}$, according to Guffy and Fraser ${ }^{7)}$. This concept to predict flow rate is rational because it is based on actual phenomenon. Here, the flow rate is finally to be predicted by expressing energy loss by using average velocity and pressure on the selected cross-section of the stream tube. Since the lost energy term needs to be analysed by using CFD, the authors ${ }^{8)}$ have conducted both wind tunnel test and CFD to verify its accuracy regarding the stream tube passing through the building model by measuring flow quantities along the central line of the model, which is regarded to be relatively easy. Considering estimation of energy loss due to divergence and convergence of the stream tubes, pressure and velocity must be measured for also around the model. Therefore, this paper examines flow characteristics and accuracy of CFD around the building by using the same model as used in the previous work ${ }^{8)}$. To obtain velocity distribution, 2-D Particle Image Velocimetry (PIV) is used. For pressure, on the other hand, the five-hole pitot tube is used because this facilitates to measure spatial pressure, velocity and wind direction where wind direction is not known. Obtained results are compared with CFD results to verify accuracy of simulation. Both experimental techniques have advantages and disadvantages and consequently their scopes are also to be discussed at the same time.

This article collects and recomposes the outcomes presented in the published conference papers ${ }^{14115)}$.

*1 Lecturer, Department of Architecture and Urban Design, College of Science and Engineering, Ritsumeikan University, Dr. Eng.

* 2 Assoc. Prof., Division of Global Architecture, Graduate School of Engineering, Osaka University, Dr. Eng.

* 3 Prof., Division of Global Architecture, Graduate School of Engineering, Osaka University, Dr. Eng.

* 4 Prof., Division of Global Architecture, Graduate School of Engineering, Osaka University, Dr. Eng.

* 5 Assistant Prof., Division of Global Architecture, Graduate School of Engineering, Osaka University, Dr. Eng.

* 6 Graduate Student, Department of Architecture, Graduate School of Engineering, the University of Tokyo

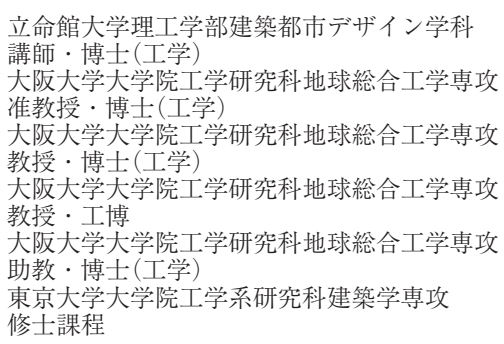




\section{Comparison of Flow Pattern between PIV and CFD}

\subsection{Summary}

$\Lambda$ closed-circuit wind tunnel in Osaka University was used for the measurement, whose working section has a dimension of $1,800 \mathrm{~mm}$ high, $1,800 \mathrm{~mm}$ wide, and $11,000 \mathrm{~mm}$ long. The test model has a configuration shown in Fig. 1 having nine one-room residences where only openings of the central room are assumed to be open. The model was located at the centre of the tunnel and exposed to a free flow of $10 \mathrm{~m} / \mathrm{s}$ varying the side length of the opening to be $15,30,45,60$, and $90 \mathrm{~mm}$, which is the same as the previous work ${ }^{8}$. Here, all walls are made of acrylic board of which thickness is 6.0 $\mathrm{mm}$ for side walls and $3.0 \mathrm{~mm}$ for end walls.

PIV measurement is an experimental technique estimating velocity by taking several photographs of the visualized flow in a known time interval. By detecting spatial shift of the tracer within each interrogation window, velocity distribution is obtained. Fig. 2 gives a schematic of the experimental set-up. A smoke generator (KANOMAX JAPAN, 8304) was located outside of the wind tunnel and the tracer was injected into upstream part of the wind tunnel. A double pulse Nd:YAG laser (NEWWAVE RESEARCH, DPIV-N50) was located outside and the laser sheet was oriented horizontally through a transparent acrylic window of the wind tunnel. Visualized flow was captured by a CCD camera located above the wind tunnel. The measurement was conducted for 25 seconds at the frequency of $4.0 \mathrm{~Hz}$. For one set of photography, two pictures were taken within $200 \mu$ s of time interval, i.e., 100 pairs of pictures in total.

Two regions of which size is $625 \mathrm{~mm} \times 471 \mathrm{~mm}$ shown in Fig. 3 are measured separately to capture complicated flow field in the wake generated by relatively large facade. Analysis was done by Davis 7.2 (La Vision), and the CCD camera and the laser were also controlled by this program. For velocity estimation, FFT cross-correlation method ${ }^{9)}$ was used. The recursive correlation method ${ }^{10)}$ was applied to improve both statistical confidence and spatial resolution. Here, calculation of the instantaneous cross-correlation distribution was repeated three times varying the size of interrogation window. Table 1 gives the summary of PIV setting.

The obtained results from measurement are to be compared with CFD results using three turbulence models, i.e., Standard k- $\varepsilon$ Model (SKE), Reynolds Stress Model (RSM), and Large Eddy Simulation (LES), which have been conducted in the preceding work. Given the free flow of approaching wind in the experiment without any roughness element, the inlet boundary condition of X-velocity was assumed to be $10.0 \mathrm{~m} / \mathrm{s}$ constantly for LES simulation. For details, see Asai et al. ${ }^{8)}$ Table 2 and Table 3 shows the summary of CFD analyses for RANS and LES calculation. Fig. 4 illustrates the computational domain used in RANS analyses.

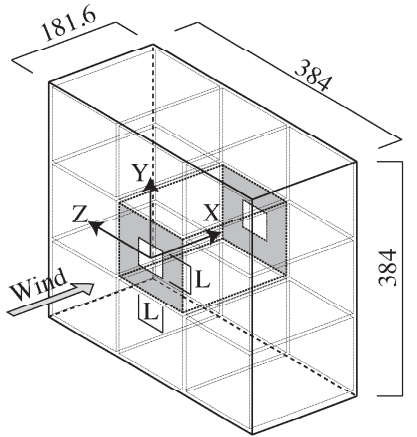

Fig. 1 Studied Model (Dimensions in $\mathrm{mm}$ )

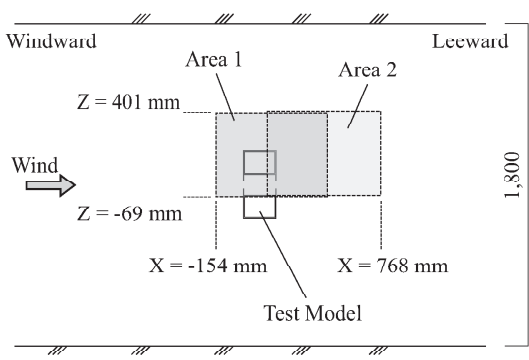

Fig.3 Measured Region in PIV Table 1 Setting of PIV Measurement

\begin{tabular}{c|c}
\hline Camera Frame Size & $\begin{array}{c}625 \mathrm{~mm} \times 471 \mathrm{~mm} \\
1,376 \text { pixel } \times 1,040 \text { pixel }\end{array}$ \\
\hline Program & Davis 7.2 \\
\hline Algorithm & $\begin{array}{c}\text { FFT Cross-Corrclation Mcthod } \\
\text { Recursive Correlation Method })\end{array}$ \\
\hline Interrogation & $\begin{array}{c}\text { Pass } 1: 64 \text { pixel } \times 64 \text { pixel } \\
\text { Pass } 2: 32 \text { pixel } \times 32 \text { pixel }\end{array}$ \\
Window Size & Pass 3:32 pixel $\times 32$ pixel \\
\hline Overlap & $50 \%$ \\
\hline Total Numver of Vectors & $5,590(86 \times 65)$ \\
\hline Time Interval of Pulse & $200 \mu \mathrm{s}$ \\
\hline Sampling Frequency & $4.0 \mathrm{~Hz}$ \\
\hline Sampling Time & $25 \mathrm{~seconds}$ \\
\hline Laser Output & $50 \mathrm{~mJ} /$ Pulse \\
\hline Sceding Sizc & $0.3-1.0 \mu \mathrm{m}$ \\
\hline
\end{tabular}

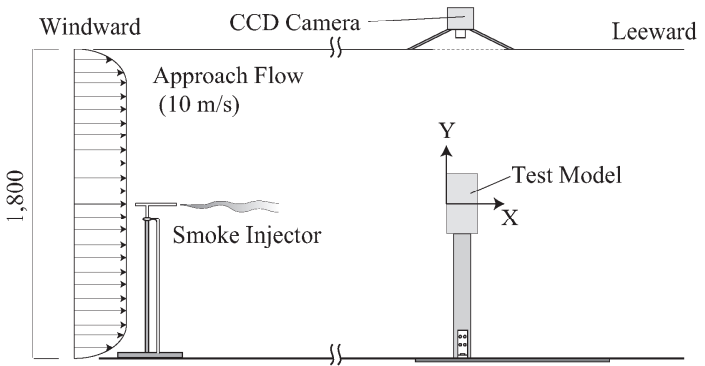

(1) $\mathrm{X}-\mathrm{Y}$ cross-section

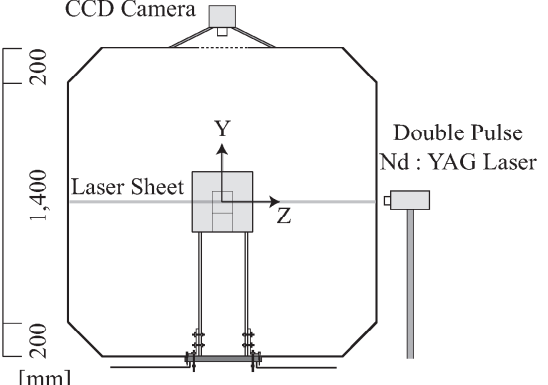

(2) Y-Z cross-section
Fig. 2 Schematic of the PIV Measurement
Table 2 Summary of RANS Analyses RANS (Reynolds Averaged Navier-Stokes Equation)

\begin{tabular}{|c|c|c|}
\hline \multirow{2}{*}{\multicolumn{2}{|c|}{$\begin{array}{l}\text { CFD Code } \\
\text { Turbulcnce Model }\end{array}$}} & Fluent 6.3 \\
\hline & & $\begin{array}{c}\text { Standard k-\& Model (SKE) } \\
\text { Reynolds Stress Model (RSM) }\end{array}$ \\
\hline \multicolumn{2}{|c|}{ Algolithm } & Implicit Method (SIMPLE) \\
\hline \multicolumn{2}{|c|}{$\begin{array}{l}\text { Discretization Scheme for } \\
\text { Advection Term }\end{array}$} & QUICK \\
\hline \multirow{4}{*}{ Boundary Condition } & Inlet & $\begin{array}{l}\text { Volocity : } 10 \mathrm{~m} / \mathrm{s} \\
\text { Turbulent Intensity : } I=1 \% \\
\text { Turbulent Length Scale : } \Lambda=126 \mathrm{~mm}\end{array}$ \\
\hline & Outlet & Gauge Pressure: $0 \backslash \mathrm{Pa} \mid$ \\
\hline & \multirow{2}{*}{ Walls } & Walls : Generalized Log Low \\
\hline & & Symmetry : free slip \\
\hline \multirow{4}{*}{\multicolumn{2}{|c|}{ Total Number of Cells }} & $\mathrm{L}=15 \mathrm{~mm}: 1,612,128$ \\
\hline & & $\begin{array}{l}\mathrm{L}=30 \mathrm{~mm}: 1,612,648 \\
\mathrm{~L}=45 \mathrm{~mm}: 1,685,808\end{array}$ \\
\hline & & $\mathrm{L}=60 \mathrm{~mm}: 1,685,808$ \\
\hline & & $\mathrm{I}=90 \mathrm{~mm}: 1,619,688$ \\
\hline
\end{tabular}

$1,000 \quad 181.6$

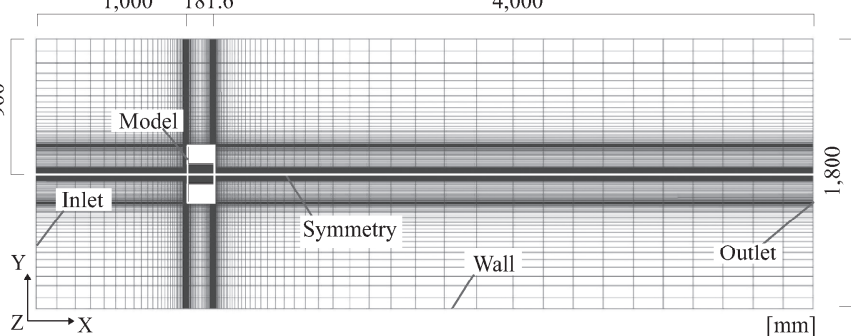

(1) X-Y Cross-Section
Table 3 Summary of LES Analyses

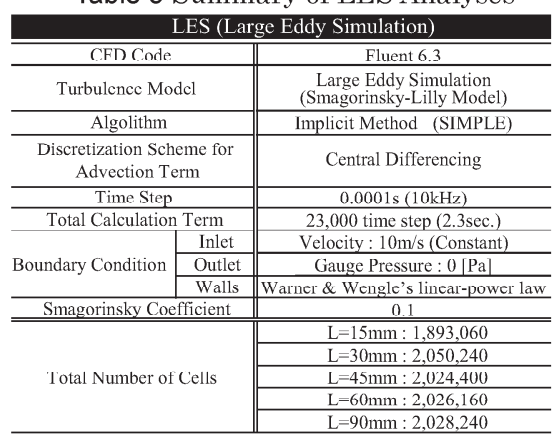

1,800

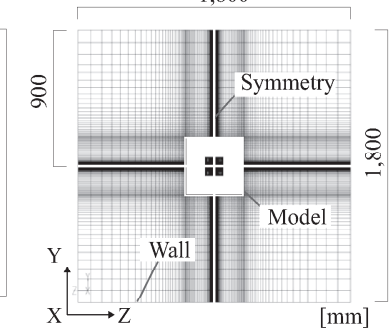

(2) Y-7, Cross-Section
Fig.4 Computational Domain of CFD analysis Simulating Wind Tunnel Experiment for RANS Model 


\subsection{Results and Discussion}

Fig. 5 shows the velocity vectors obtained from PIV and CFD for $\mathrm{L}=15$, 45 , and $90 \mathrm{~mm}$. Here, the vector plots shown in the figure are omitted to be one-sixteenth of all (one-fourth in $\mathrm{X}$ and $\mathrm{Z}$ direction), and the results in two regions measured separately are combined.

In PIV results, the separation angle seems to be almost independent of opening size. On the leeward side of the model, a back flow due to the large wake is generated. The discharged flow from the opening collides to this back flow, flows toward the windward corner, and involved into the wake or flows downstream. The PIV results inside a room do not seem to be symmetry in $\mathrm{Z}$ direction. This is due to that the laser sheet transmitted through two acrylic boards to be weakened. Given the restricted objective to see external flow field, however, this decrease of accuracy is not important.

Comparing CFD and PIV results, RSM cannot simulate the vortex on the leeward side and overestimates the separation region. On the other hand, the results from SKE seem to be similar to the experimental results if compared with RSM, but the size of separation region and the separation angle differ from PIV. Regarding LES results, the back flow cannot be seen only in the case of $\mathrm{L}=90 \mathrm{~mm}$. In other cases, however, flow pattern of LES well agrees with PIV results qualitatively, and it can be said that LES yielded somewhat improved results from those of RSM and SKE at least for flow pattern.

\section{Calibration of Five-Hole Pitot Tube}

Since the PIV system cannot measure pressure that is also required to estimate transported power, pressure distribution was also measured by using the five-hole pitot tube. This device enables to measure static pressure, velocity magnitude, and wind direction simultaneously. Fig. 6 depicts the five-hole pitot tube used in this work, of which sensing head is spherical (4.0 mm diameter) and provided with five pressure holes. Pressure holes $n_{1}$ to $n_{1}$ are along the lines inclined 45 degrees against an axis through centre of sensing head and pressure hole $\mathrm{n}_{0}$. The basic principle to operate a fivehole pitot tube is that the central pressure hole $\mathrm{n}_{0}$ towards wind direction when other four pressure holes show the same pressure reading ${ }^{11}$. Based on pressure reading of $\mathrm{n}_{0}$, velocity magnitude is obtained when the pressure distributes uniformly. Although this method is relatively simple, to rotate the probe in 3-D is not realistic for the measurement. Another method ${ }^{12)}$ without rotating probe but to use calibration charts, has also been proposed. However, this is not appropriate for automatic computation of flow quantities. In such a background, Wright ${ }^{13)}$ has introduced an advanced calibration method without rotation including three advantages, i.e., 1) simplified calibration curves, 2) reduced the probability of misinterpretation of the data, and 3) become suitable for automatic computation after measurement. In estimating wind direction, this calibration method adopts two kinds of wind angle
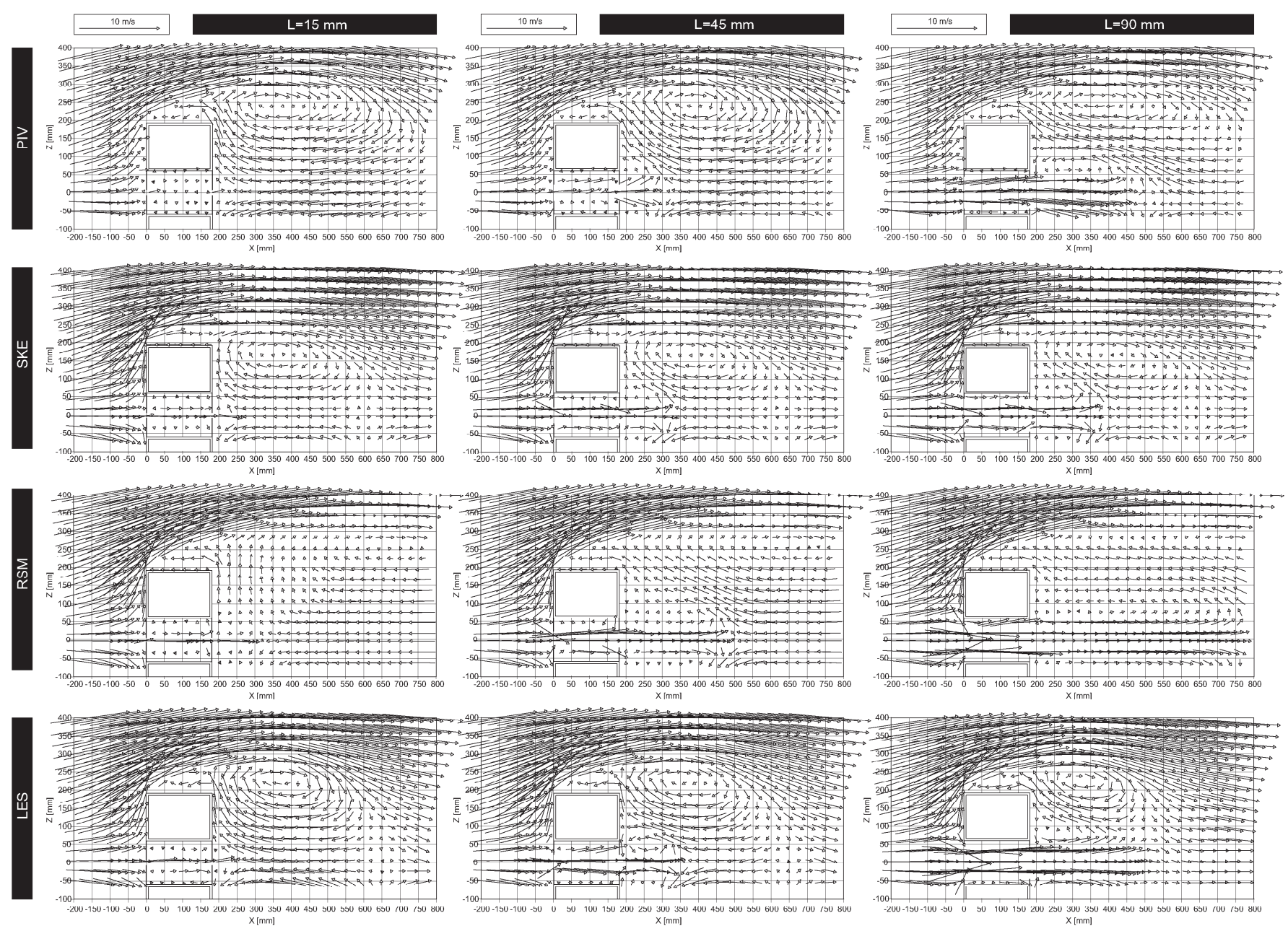

Fig. 5 Velocity Vector Plots obtained from PIV and CFD 
shown in Fig. 7, i.e., conical angle and dihedral angle. The conical angle $\phi$ is formed by the velocity vector and the probe axis. The dihedral angle $\delta$ is between the flow plane and the meridian plane. To estimate wind direction, velocity magnitude, and static pressure based on pressure reading of five holes, three parameters were defined as follows,

$$
\begin{aligned}
& K_{\phi}=\left[1-\sum_{n=1}^{4}\left(p_{0}-p_{n}\right) / 2\left\{\sum_{n=1}^{4}\left(p_{0}-p_{n}\right)^{2}\right\}^{1 / 2}\right]^{1 / 2} \\
& K_{V}=\left[\rho V^{2}\left\{\sum_{n=1}^{4}\left(p_{0}-p_{n}\right)^{2}\right\}^{-1 / 2}\right]^{1 / 2} \\
& K_{p}=2\left(p_{0}-p_{S}\right) / \rho V^{2}
\end{aligned}
$$

where, $K_{\phi}$ is angle factor, $K_{V}$ is velocity factor, and $K_{P}$ is pressure factor. $p_{0}$ and $p_{n}$ are pressure reading corresponding to each pressure hole, and $p_{S}$ is the static pressure of the measurement point. To obtain conical and dihedral angles, velocity, pressure, one more relation is required, which is given as,

$$
\tan \delta=-\left(p_{2}-p_{4}\right) /\left(p_{1}-p_{3}\right)
$$

It was shown that three parameters are given by conical angle $\phi$, and almost independent of dihedral angle $\delta^{13}$. Therefore, by arranging calibration curve for each factor as a function of conical angle, the simultaneous measurement

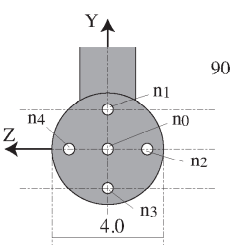

(1) Front elevation

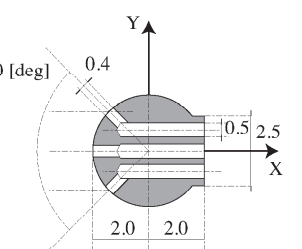

(2) Side cruss-sectiun

Fig.6 Configuration of the Sensing Head

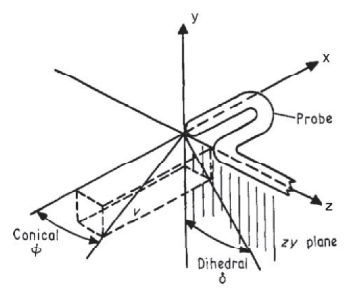

Fig.7 Definition of Angles ${ }^{13}$ of wind direction, velocity magnitude, and static pressure was enabled.

The calibration measurement was conducted in the same wind tunnel as PIV measurement. Here, the five-hole pitot tube was installed on the arm attached to the traverser and exposed to a free flow of $10 \mathrm{~m} / \mathrm{s}$ with the probe rotatable. Since the measurement around the test model in the following chapter is done on the horizontal plane through the centre of the model, the dihedral angle was fixed to be 90 degrees and the pressures were measured at every 2 degrees of rotation angle by using a manometer (MP45 and DP103, Validyne). Five pressure readings were recorded simultaneously for 60 seconds with a sampling frequency of $100 \mathrm{~Hz}$. $\Lambda$ s the reference static pressure, static pressure of normal pitot tube (JIS-type, LK-1, Okano works) was adopted, which was located $300 \mathrm{~mm}$ away from the side wall of the tunnel. To calculate pressure factor, static pressure at the centre of the wind tunnel was measured separately by using the same type of normal pitot tube.

Fig. 8 shows pressure reading of each pressure hole. Here, the dihedral angles estimated from these results are also shown just for reference. $p_{1}$ and $p_{3}$ show almost the same results and $p_{2}$ and $p_{4}$ resulted in symmetry distribution because the probe was rotated horizontally. In addition, it can be confirmed that the dihedral angle was fixed to be almost 90 degrees. Since it cannot be defined when the flow approaches exactly from the front of the sensing head, dihedral angle decreases for conical angle close to 0 degree.

Based on recorded pressure reading of the five pressure holes, angle factor, velocity factor, and pressure factor are obtained as shown in Fig. 9 where calibration curves are given as a function of the conical angle by polynomial approximation. By using these calibration curves, in the following chapter, flow quantities around the test model are to be presented.
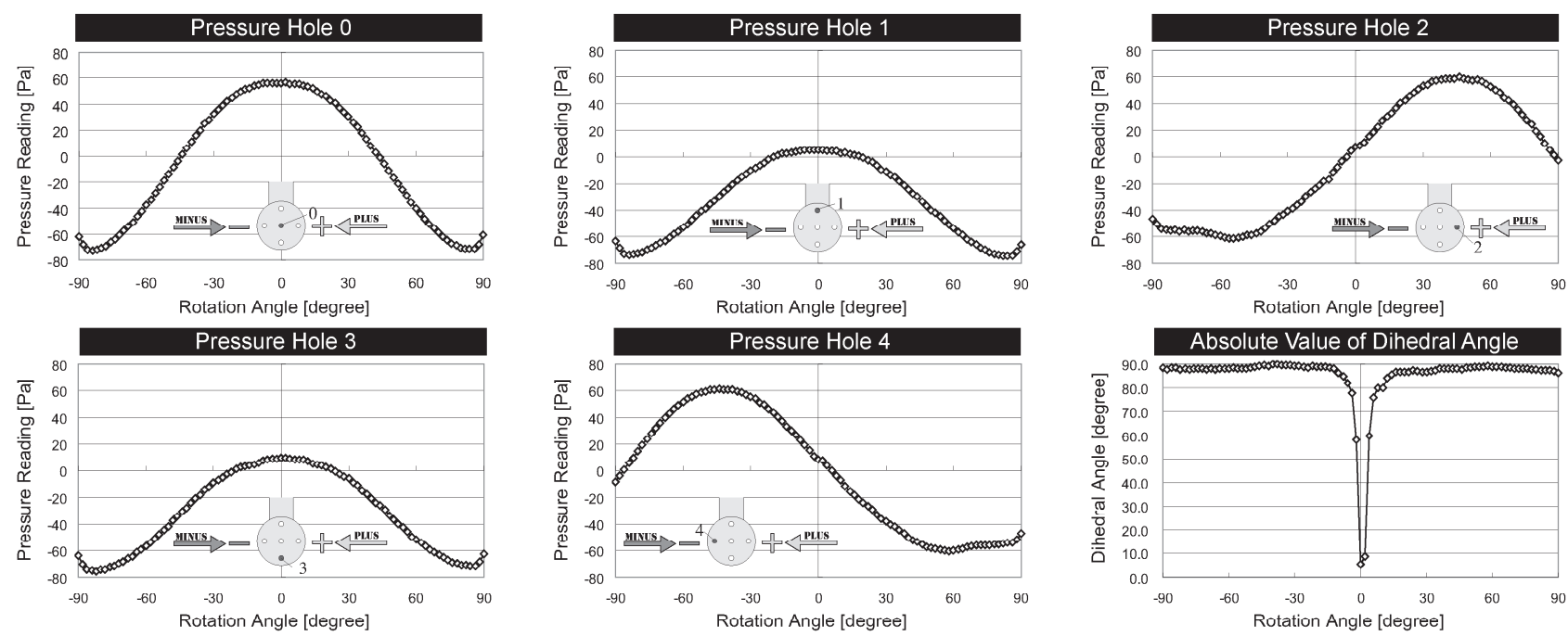

Absolute Value of Dihedral Angle

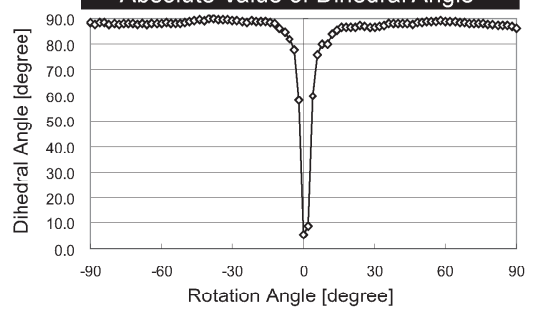

Fig.8 Pressure Reading of each Pressure Hole and Absolute Value of Dihedral Angle
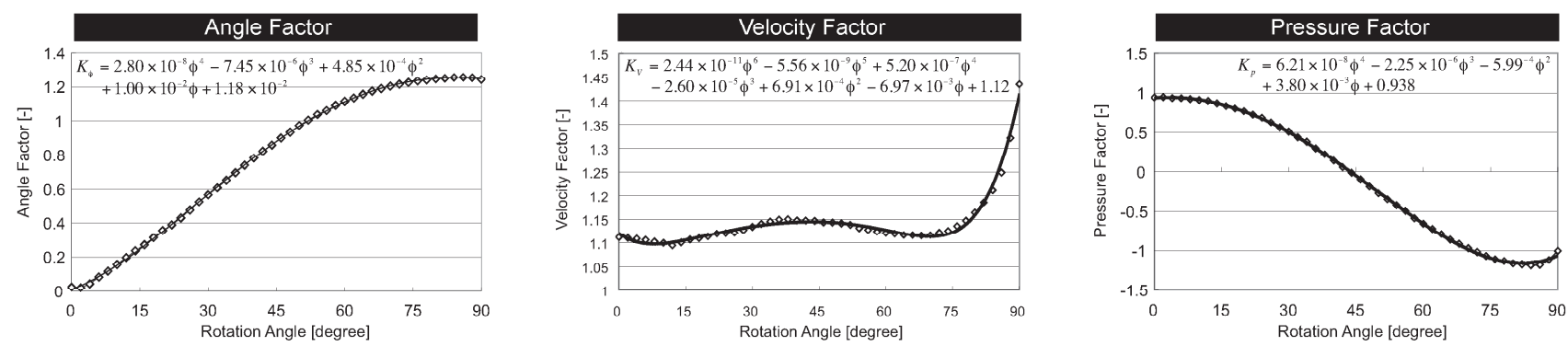

Fig. 9 Calibration Curve of Angle Factor, Velocity Factor, and Pressure Factor 


\section{Accuracy of CFD and Scope of Experimental Technique}

Since PIV and five-hole pitot tube seem to have strength and weakness, the reliability of each experimental result depends on location of the measurement point. In order to explore the scope of experimental techniques and to verify accuracy of (FD analyses, flow quantities are measured around the cross-ventilated building model by using five-hole pitot tube for the case of $\mathrm{L}=45 \mathrm{~mm}$. As well as PIV measurement shown above, the test model was located at the centre of the wind tunnel and exposed to a free flow of $10 \mathrm{~m} / \mathrm{s}$. The probe was attached to an arm fixed to the 3-D traverser. The experimental set-up is shown schematically in Fig. 10. The measurement points are distributed on the central plane horizontally as shown in Fig 11. The probe was basically set toward the wind direction of 0 degree in the side region of the test model (separation region). However, since there might be back flow for the black plots in Fig. 11 which are relatively close to the side wall of the model, the measurement was also conducted with its sensing head toward to the wind direction of 120 degrees. Conical angle $\phi$ was estimated based on the quartic function of $K_{\phi}$ in the range of \pm 75 degrees by using bisection method. For the measurement on the windward side, the sensing head was fixed toward wind direction of +15 degrees to enable to measure the flow along the windward wall. The sampling condition and the reference static pressure were the same as those of calibration experiment.

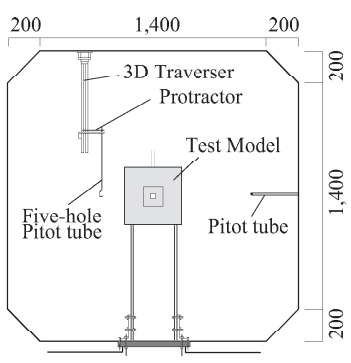

(1) Y-Z Cross-Section

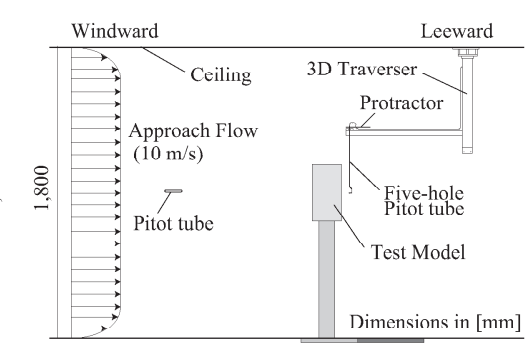

(2) X-Y Cross-Section

Fig.10 Schematic of the Measurement using Five-Hole Pitot Tube
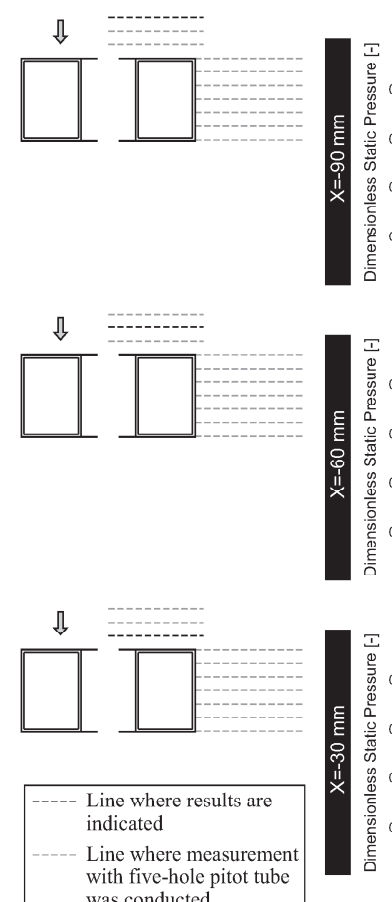
with five-hole pitot tube was conducted
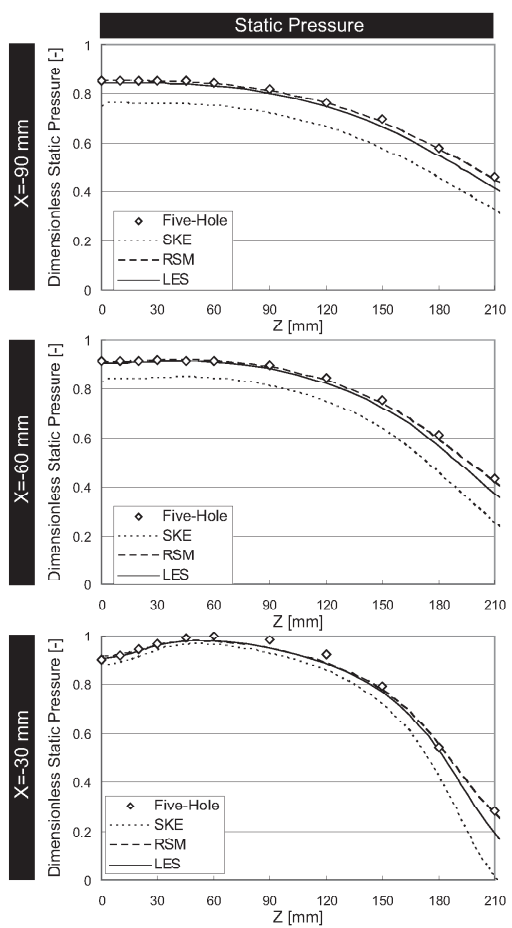
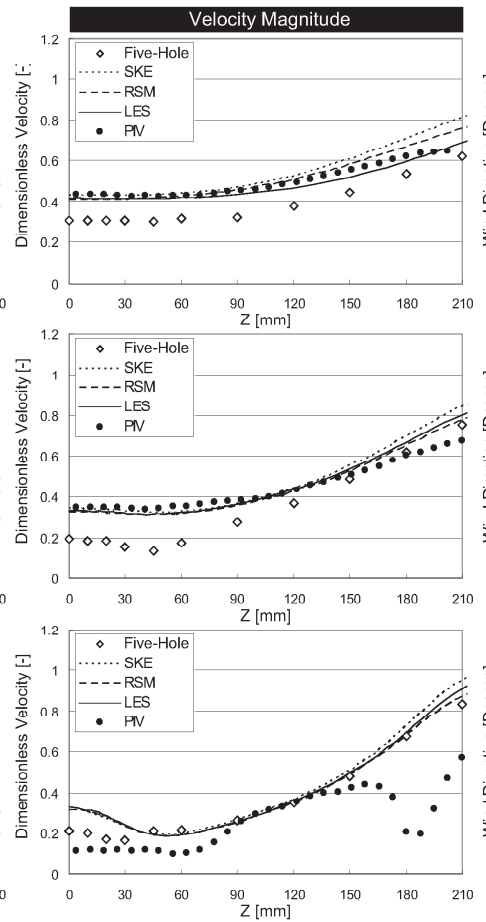

Fig. 12 gives horizontal distribution of static pressure, velocity magnitude, and wind direction along three lines $(X=-30,-60$, and $-90 \mathrm{~mm})$ in $Z$ direction. Here, results from PIV, five-hole pitot tube, and CFD are shown all together. The static pressure was nondimensionalized by total pressure on the measurement point of $X=0, Z^{\prime}=432 \mathrm{~mm}$ (distance from the side wall $\left(L^{\prime}\right)$ is $240 \mathrm{~mm}$ ). The velocity was also shown as dimensionless value by dividing it by approaching velocity.

The static pressure obtained from SKE is lower other results. On the other hand, good correspondence of static pressure can be seen among RSM, LES, and the measurement using the five-hole pitot tube. $\Lambda$ s for the velocity magnitude and wind direction from PIV measurement and CFD, all results show almost the same distribution for the lines of $X=-60,-90 \mathrm{~mm}$, but for the line of $X=-30 \mathrm{~mm}$, PIV results shows obviously unnatural distributions. This is due to that the laser sheet was oriented from the side of the model and it transmitted through acrylic boards. Regarding velocity and wind direction from the five-hole pitot tube, the results are not reliable especially in the region adjacent to the windward wall. Here, wind direction of 90 degrees indicates that the angle factor exceeded the maximum value of the calibration curve, and the wind angle -60 degrees, smaller than minimum value. The operation of the five-hole pitot tube is supposed to be conducted under the uniform pressure distribution around the sensing head. However, the flow on the windward side impinges on the wall, and consequently pressure gradient

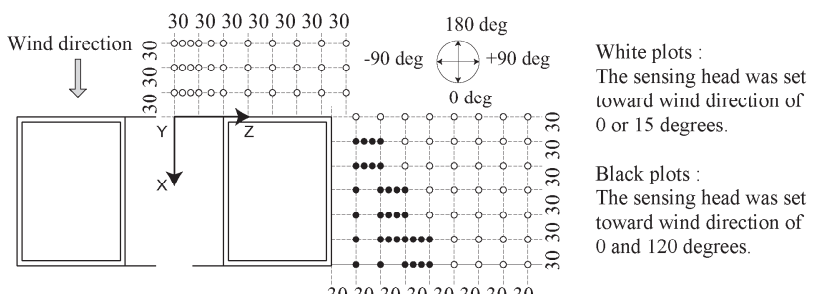

Fig.11 Meausrement Points around Test Model $(\mathrm{L}=45 \mathrm{~mm})$

Fig.12 Distribution of Pressure, Velocity, and Wind Direction obtained from Five-Hole Pitot Tube, PIV, and CFD on the Windward Side 
becomes large. For such flow field, five-hole pitot tube is not appropriate for velocity measurement. The rationale of good agreement of static pressure measured by this device is that the static pressure is estimated based on Eq.4, which includes pressure reading of the central pressure hole $\mathrm{n}_{0}$ only and there is no effect of pressure gradient around sensing head. In addition, according to Eq. 4, the error in estimating velocity does not make significant effect on the static pressure because velocity itself is small around impinging region.

Fig. 13 shows the flow quantities in the side region of the test model obtained from the five-hole pitot tube, PIV, and CFD as well. Here, the results along the measurement lines $X=30,90,150 \mathrm{~mm}$ are omitted. On the measurement point where two results of probe angle exist ( 0 and 120 degrees), they were compared and proper one was adopted in advance.

For the side region of the test model, RSM showed better agreement with experimental results than other two turbulence models regarding static pressure. However, results from SKE and LES also could simulate the tendency well and the pressure distributions are not significantly different from experimental results. As for the velocity magnitude, the five-hole pitot tube, RSM and LES resulted in almost the same distribution for all lines. Only the results of SKE show smaller velocity gradient along the lines of $X=120$, and $180 \mathrm{~mm}$. PIV result along the measurement line of $X=0 \mathrm{~mm}$ shows obviously small velocity around the side wall. This may be caused by large velocity gradient around the windward corner. Since recursive correlation method uses the distribution of the cross-correlation in the larger interrogation window to detect the velocity in the smaller interrogation, there might be large velocity gradient in one interrogation window. In addition, the cross-correlation of the target interrogation is influenced by surrounding information. Due to these factors, large velocity gradient tends to be underestimated in PIV. For other measurement lines, PIV results seem to be reliable and almost the same as those of RSM, LES and five-hole pitot tube.

Moving to wind direction, the location of extreme variation indicates the boundary of the separated flow (180 degrees indicates a back flow along the side wall). For wind direction, it is believed that PIV measurement is the most reliable except the line of $\mathrm{X}=0 \mathrm{~mm}$ because there exists no factor causing detection error of cross-correlation peak in this measurement region. For outside of the separation region where wind direction is small, all results show similar results. Inside the separation region, SKE generally underestimates its size, RSM shows the best agreement with PIV result, and LES resulted in similar distribution to that of PIV. As for the five-hole pitot tube, the location of separation boundary is well measured, but the angle is a little underestimated inside the separation region, even though velocity could be measured well. This discrepancy could be caused by that the flow is highly turbulent in this region, and the estimated conical angle was affected. The reason for good agreement of velocity seems to be that velocity factor is not as sensitive as angle factor to the conical angle in the range of \pm 75 degrees, and it can be said that the decrease of accuracy to estimate the wind direction due to the turbulence was not significant for the separation region.
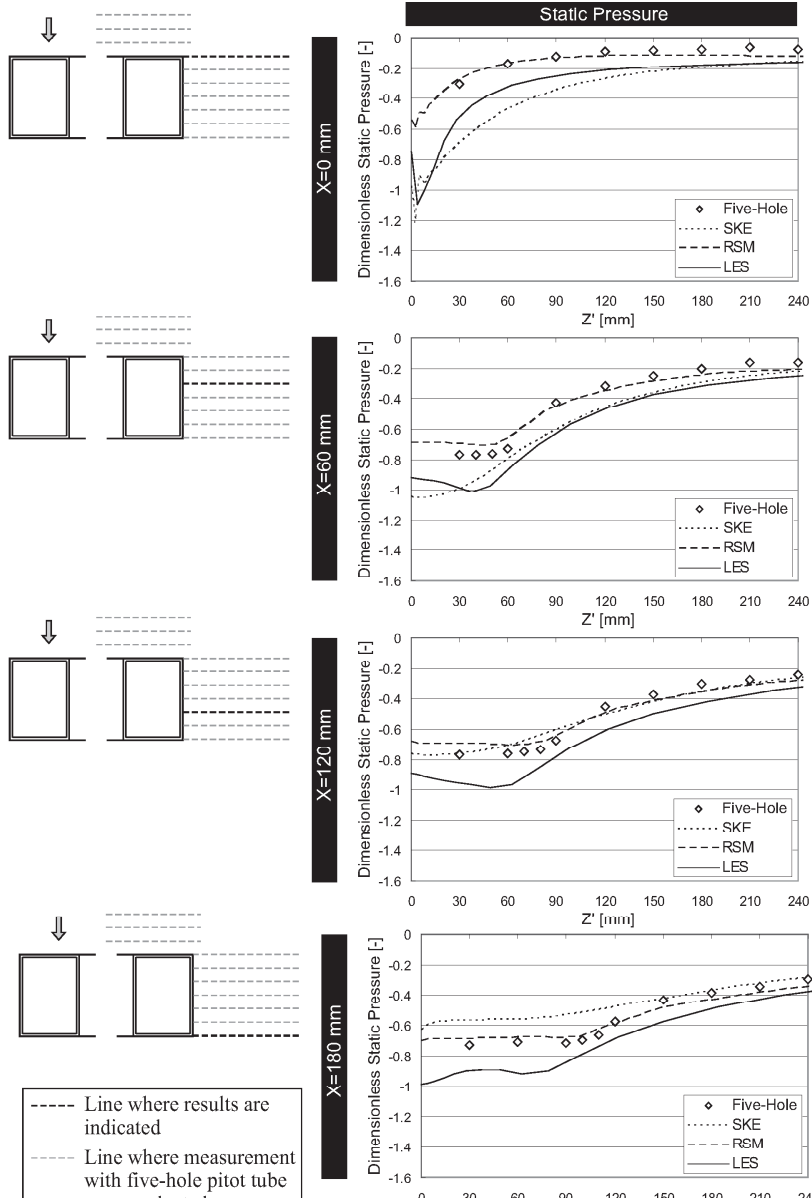
with five-hole pitot tub
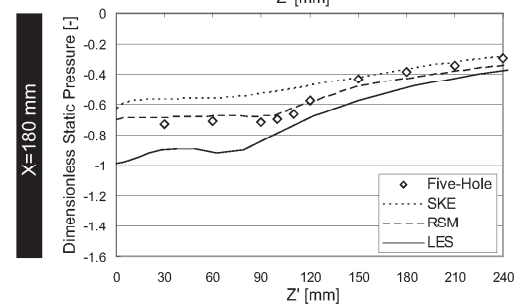
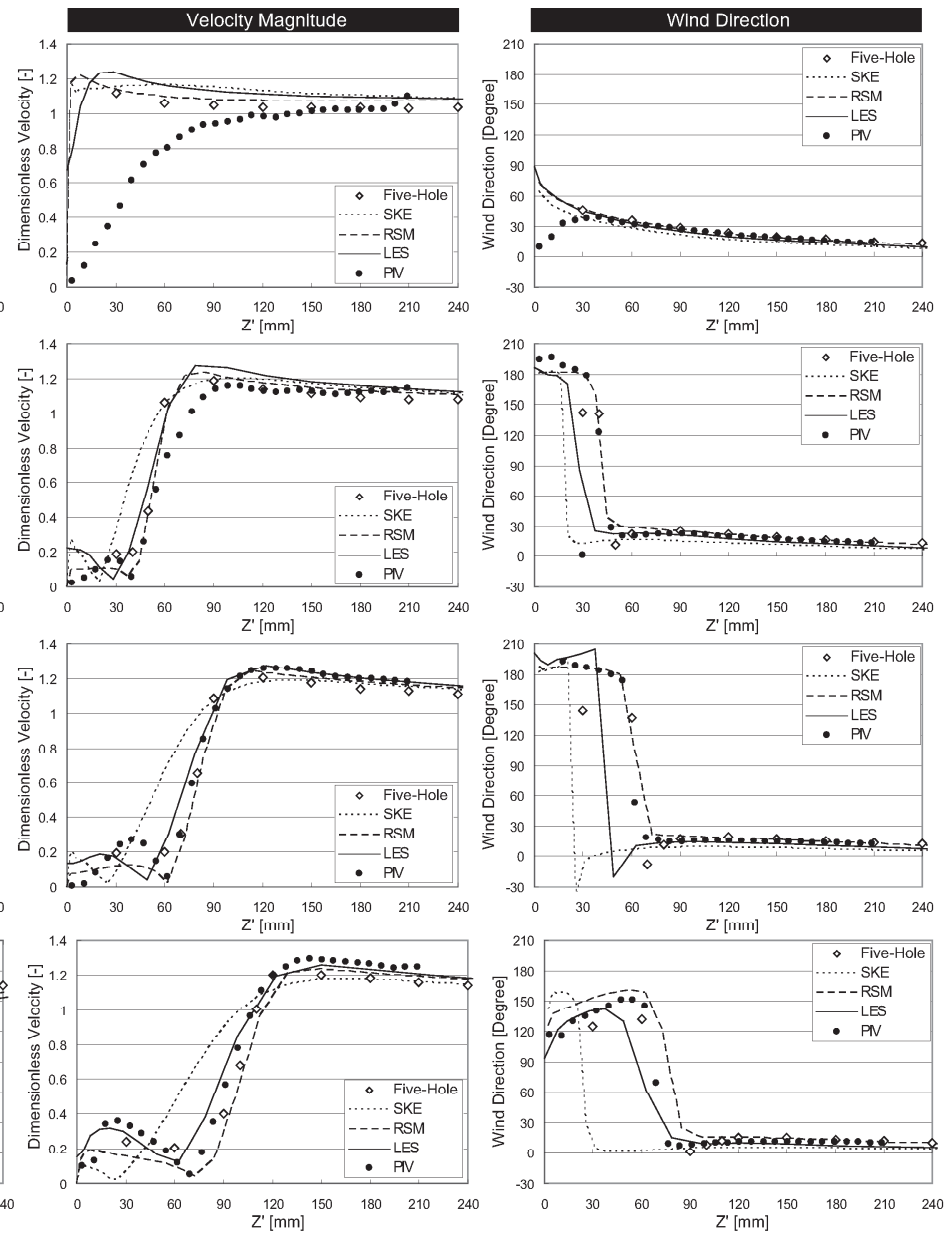

Fig.13 Distribution of Pressure, Velocity, and Wind Direction obtained from Five-Hole Pitot Tube, PIV, and CFD in the Side Region 


\section{Conclusions}

The final goal of this work is to analyse the power transportation inside the stream tube by using CFD for prediction of cross-ventilation rate of the building. For this objective, this paper verified the accuracy of CFD analyses using three turbulence models, SEK, RSM and LES, especially for the external flow field, which were simulating the wind tunnel test for the crossventilated building model. Since there exists no universal measurement technique for pressure and velocity, those flow quantities were measured by using two experimental devices, i.e. 2-D PIV system and five-hole pitot tube. In studying accuracy of CFD, the scopes of these devices were also discussed. The conclusions are summarised as follows.

1) The flow pattern around the test model was analysed by PIV, and simulated by CFD analysis. SKE could simulate flow pattern well qualitatively, but separation angle and the size of vortex on the leeward side were different from experimental results. RSM obviously overestimated the size of the wake region generated on the leeward side. LES showed good agreement with PIV results, though the back flow could not be seen only in the case of the largest opening.

2) The static pressure from SKE was underestimated on the windward side, and the gradient became small around the windward corner. On the other hand, RSM could simulate static pressure very well in the windward and side region. Although LES could underestimate the static pressure, the difference from experimental result was not significant.

3) Although PIV measurement has strength to obtain velocity distribution relatively easily, it might not be able to detect the cross-correlation peak appropriately around the windward corner because of large velocity gradicnt.

4) There exist problems in using five-hole pitot tuhe for the measurement on the windward side and inside the separation region because of large pressure gradient and turbulence respectively. For the former, estimated velocity magnitude and wind direction were extremely affected but its effect on estimated static pressure was almost negligible because of low velocity due to impingement. The latter, pressure was not affected due to low velocity as well. Velocity magnitude could also be measured well hut the wind direction could he affected hecause velocity factor was not as sensitive as angle factor to conical angle.

From the comparison between CFD and measurement presented in this paper, the accuracy of CFD analyses regarding external flow field has been verified. Considering correlation of qualitative flow pattern, static pressure, velocity magnitude, and wind direction, LES showed sufficiently good agreement with experimental results. Since the authors ${ }^{8}$ have also validated this numerical result for the flow inside the room, the results from LES simulation is to be used for the analyses of power transportation inside stream tube in the following works.

\section{Acknowledgement}

The authors are deeply grateful to Mr. Tatsuya Yamashita (SANKI Engineering) for lending us manometers required for the measurement with five-hole pitot tube. The help from Ms. Yasue Tanaka and Mr. Yasuhiro Shiozaki (KANOMAX Japan) in conducting PIV measurement was also gratefully acknowledged. A part of this work was supported by Grant-inAid for JSPS Fellows (Representative Tomohiro Kobayashi (20-912)), Japan Society for the Promotion of Science, 2009.

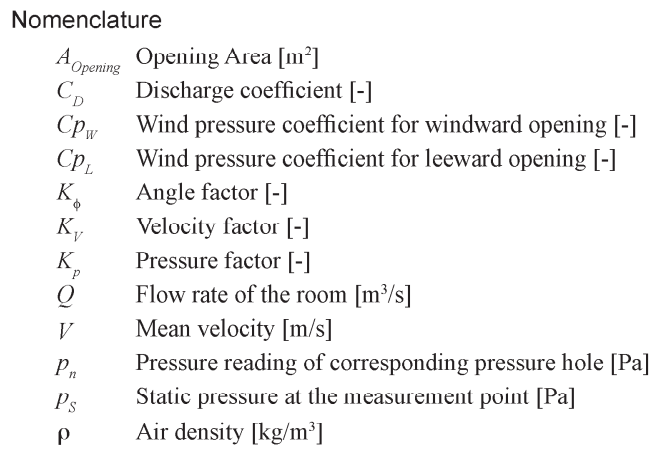

\section{References}

1) T. Kobayashi, K. Sagara, T. Yamanaka, H. Kotani, S. Takeda, and M. Sandberg Stream Tube based Analysis of Problems in Prediction of Cross-Ventilation Rate, The International Journal of Ventilation, Volume 7, Number 4, pp.321-334, 2009.

2) M. Ishihara : Building Ventialtion Design, Asakura Publishing, 1969. (In Japanese)

3) T. Kurabuchi, M. Ohba, T. Endo, Y. Akamine, and F. Nakayama : Local Dynamic Similarity Model of Cross-Ventilation - Part 1. Theoretical Framework, The International Journal of Ventilation, Volume 2, Number 4, pp.371-382, 2004.

4) H. Kotani and T. Yamanaka : Prediction of Inflow Direction at Large Opening of Cross Ventilated Apartment Building, Journal of Environmental Engineering, Transaction of AIJ, No.609, pp.39-45, 2006.11.

5) M. Sandberg: An alternative view on Theory of Cross-Ventilation, The International Journal of Ventilation, Volume 2, Number 4, pp.409-418, 2004.

6) S. Murakami, S. Kato, S. Akabayashi, K. Mizutani, and Y. D. Kim : Wind Tunnel Test on Velocity Pressure Field of Cross-Ventilation with Open Windows, ASHRAE Transactions, Volume 97, Part 1, pp.525-538, 1991.

7) S. E. Guffy and D. A. Fraser : A Power Balance Model for Converging and Diverging Flow Junctions, ASHRAE Transactions, Volume 95, Part 2, pp.2-9, 1989.

8) K. Asai, H. Kotani, T. Kobayashi, K. Sagara, T. Yamanaka, Y. Momoi : Airflow Characteristics Inside and Outside Cross-Ventilated Building - PartI. Measurement of Static Pressure and Velocity Inside Flow Path and Accuracy Study of CFD Analysis, Proceedings of Annual Meeting of SHASE Kinki Chapter, pp.69-72, 2010. (In Japanese)

9) C. E. Willert and M. Gharib : Digital Particle Image Velocimetry, Experiments in Fluids, Vol. 10, No. 4, pp. 181-215, 1991

10) D. P. Hart : Super-Resolution PIV by Recursive Local-Correlation, Journal of Visualization, Vol. 3, No. 2, pp.187-194, 2000.

11) I. L. Povkh : Aerodynamic Experiment in Mechanical Engineering, Asakura Publishing, 1969. (In Japanese)

12) C F R Nowack : Improved calibration method for a five-hole spherical Pitot probe, Journal of Physics E: Scientific Instruments, Volume 3, Number 1, pp.21-26, 1970.

13) M. A. Wright : The evaluation of a simplified form of presentation for five-hole spherical and hemispherical pitometer calibration data, Journal of Physics E. Scienific Instrumenis, Vol. 3, Number 5, pp. 356-362, 1970.

14) H. Kotani, T. Kobayashi, K. Sagara, T. Yamanaka, Y. Momoi, K. Asai : Airflow Characteristics Inside and Outside Cross-Ventilated Building - Part2. Experimental Investigation on Airflow around Building using PIV, Proceedings of Annual Meeting of SHASE Kinki Chapter, pp.73-76, 2010. (In Japanese)

15) T. Kobayashi, H. Kotani, K. Sagara, T. Yamanaka, Y. Momoi, K. Asai,: Airflow Characteristics Inside and Outside Cross-Ventilated Building - Part3. Measurement of Velocity and Pressure around Building using Five-IIole Pitot Tube, Proceedings of Anmual Meeting of SHASE Kinki Chapter, pp.77-80, 2010. (In Japanese) 


\section{和文要約}

\section{1.はじめに}

大開口を有寸る建物の通風時には従来の風力換気量予測手法の精 度が低トすることがわかっており口，この問題に対してこれまでに 種々の試み ${ }^{2-5}$ 名提案されてきたが，実用的な精度を有する予测手法 は確立されていない。本研究では通風時の室内外の流管に着目し, 流管内エネルギーのバランス式に基づいた予測手法 ${ }^{677)}$ の確立を目指 している。しかし，実際に流管内部で生じるエネルギーの損失量及 び輸送量を予測する千法は現時点で示されておらず，これらを明ら かにするためには CFD 解析が有効と考えられる。筆者ら ${ }^{8)}$ はこれま でに流管の解析を行う前段階として簡易な建物模型を用いて風洞害 験と CFD 解析を行い, 室内を通り拻ける流管に関する解析精度の検 証を行った。しかし，建物の外側を通過する流管との合流や分流に よるエネルギー損失を評価するためには、建物外の解析精度の検証 も必要となる。本論文はPIV と 5 孔ピトー管を用いて建物外の風向・ 風速・静圧の測定を行い、測定于法の適用範团に関して検討を行う と共に建物周辺気流の解析の精度の検証を行うものである。

\section{PIV とCFDによる気流場の比較}

\section{1 実験及び解析概要}

PIV 測定は既往の研究 ${ }^{8)}$ で用いた簡易な形状の建物模型（図 1）を 風洞中央に設置して行った。この際, 図 2 に示寸ようにCCD カメラ は風洞上部に, レーザーを側方に設置して水平に照射し，トレーサ は上流側から注入した。開口サイズは $\mathrm{L}=15,30,45,60,90 \mathrm{~mm}$ の 5 条 件とし, 表 1 に示す条件で測定を行った。また、風上側での剥離性 状と後流で形成される複雑な Wakc の両方を測定するため, 測定領域 は図 3 に示寸 2 領域とした。CFD解析は既往の研究 ${ }^{8)}$ で行った結果 を用いた。乱流モデルは標準 k-£モデル（SKE），応力方程式モデル (RSM), Large Eddy Simulation（LES）の3 種を用い，図 4 に示す解 析領域で計算を行った。解析概要は表 2 及び表 3 に示す。

\section{2 結果と考察}

図 5 に示す風速べクトルにおいて, PIV 測定結果に関しては室内U 気流は対称になっていないが，これはレーザーが 2 枚のアクリル板 を透過して弱まったことが影響したと考えられる。建物模型周辺の CFD 解析精度に関しては, SKE は定性的には PIV 結果と一致してい るが剥離角度やWake をやや過小評価する傾向となり，RSM では後流 の渦が再現されておらず, Wake のサイズを過大評価していることが わかる。LES の結果は $\mathrm{L}=90 \mathrm{~mm}$ 条件で模型後方の逆流が再現されて いないが，これを除くと㬰験結果と良く一致していることがわかる。

\section{5 孔ピトー管の較正実験}

定性的な気流性状に加え, 建物模型周辺の静圧・風速・風向の解 析精度も定量的に評価するために, 図 6 に示す 5 孔ピト一管を用い る。5 孔ピトー管の作動原理 ${ }^{11)}$ は静圧孔 $\mathrm{n}_{1}$ から $\mathrm{n}_{4}$ における圧力の読 み值が同じ值を示すようプローブを回転させた場合に静圧孔 $\mathrm{n}_{0}$ の向 きが風向に正対するというものであり，こり手法はデー夕処埋も簡 易であるが，センサを 3 次元で回転させる必要があるため模型に接 触する等の問題があり採用が難しい。また，センサを回転をさせず 較止チャートを用いる手法 ${ }^{12)}$ も提案されているが, データ処埋が煩
雑となる。本研究ではプローブを回転させず，かつ比較的容易な較 正手法であるWright の手法 ${ }^{13)}$ を採用する。この手法では式 (2) （4) に示寸角度係数, 速度係数, 圧力係数上式 (5) の関係式から風向. 風速・静圧を測定する。ここでは較正実験により各係数と頂角（図 7） の関係を得る。図 8 にプローブを $10 \mathrm{~m} / \mathrm{s}$ の一様流にさらして 2 度ず つ水平に回転させた際の各静圧孔の圧力読夕值と頂角の関倸と式 (5) より得られた夾角（図 7）の関係を示す。この結果から各測定孔の対 称性と, 夾角が概补 90 度に算出されていることを確認することがで きる。得られた各係数の較正曲線を図 9 に示す。この較正結果を用 いて, 次章では建物模型周辺の風向・風速・静圧の同時測定を行う。

\section{CFD 解析の精度検証及び実験手法の適用可能範囲}

PIV 测定と同様に建物模型を風洞中央に設置し, $10 \mathrm{~m} / \mathrm{s}$ の·様流下 で 5 孔ピトー管を用いた実験を行った（図 10）。測定点は図 11 に示 すように模型の風上側と側方に設けた。ここで, 頂角は角度係数か ら \pm 75 度の範囲で算出した。風上側の測定点では壁面に沿う気流 $(90$ 度）でも測定が可能上なるよう，プローブを風向 15 度に正対するよ う設置した。また，模型側方に関しては基本的に風向 0 度に向けて 設置したが，図 11 の黒塗りプロットの位置では剥離域内部で逆向き の気流が存在する可能性が女るため, 120 度の風向に正対するように もプローブを設置して 2 度測定を行い、適切な結果を選択した。

図 12 に風上側における風向・風速・静圧の結果を示す。静圧は SKE が実験結果と異なるが, RSM と LES は良く一致している。風向 と風速は 3 種の乱流モデルに大きな差異が見られず, $\mathrm{X}=-30 \mathrm{~mm}$ の測 定ラインのみ PIV 結果と異なるが，これはレーザーがアクリル板を 透過したことが原因であり, CFD 絬果は風们・風速を適切に評価し ていると考えられる。5 孔ピト一管による風向と風速はPIV や CFD 結果と異なるが，風上壁面への衝突で大きな历力勾配が生じたこと が原因と考えられる。それにも関わらず静圧を適切に測定すること ができているのは, 式 (4) の圧力係数は $\mathrm{n}_{0}$ 以外の静圧孔の圧力分布 の影響を受けず, 衝突領域であるため風速の絶対值も小さいためと 言える。同様に建物模型側方の結果を図 13 に示す。静圧分布は RSM が㬰験結果と最も良く一致するが SKE と LES ひ結果も差異は大きく ない。風向・風速に関しては, PIV の結果は $X=0 \mathrm{~mm}$ のラインは速度 勾配が大きいことが影響して適切に算定されていないと考えられる が，その他の測定ラインでは適切な結果が得られている。5 孔ピトー 管の結果は, 乱れの影響で風向が多少小さく算定されている䇢所も 亦るが，風速は速度係数が頂角によって大きく変わらないため, PIV と良く一致して適切に算定されていると言える。CFD 解析に関して は，やはり RSM が最も良く一致しでおり，SKE は剥離域を小さく評 価し, LES もやや異なるがその差異は大きくないことがわかる。

\section{5. おわりに}

本論文では建物模型周辺の気流性状に着目し, PIV と 5 孔ピト一管 を用いて测定を行い，各测定手法の適用可能範囲上 CFD 解析の精度 に関する検討を行った。流れのパターンと風向・風速・静圧を比較 した結果, 総合的にLES の結果が最も良く実験結果と一致したと言 える。既往の研究 ${ }^{8)}$ で室内を通り抜ける気流に関しても LES は十分 な解析精度を有していたことを考慮し, 今後は本解析結果を用いて 至内外流管で輸送されるエネルギーに関する検討を行う所存である。 